\title{
PENGARUH EKSTRAK BIJI NIMBA (Azadirachta indica) TERHADAP PENURUNAN DERAJAT PARASIT DAN JUMLAH HEMOZOIN PADA KULTUR Plasmodium falciparum
}

\section{(THE EFFECT OF NEEM SEEDS EXTRACT (Azadirachta indica) ON THE DECREASING OF PARASITE LEVEL AND HEMOZOIN AMOUNT IN CULTURE OF Plasmodium falciparum)}

\author{
Noer Aini", Soebaktiningsih" ${ }^{* *}$, Loeki Enggar Fitri", Umi Kalsum ${ }^{* * *}$, Sumarno**** \\ "Program Studi Pascasarjana S2 Biomedik Universitas Brawijaya Malang \\ "Laboratorium Parasitologi Fakultas Kedokteran Universitas Brawijaya Malang \\ **tLaboratorium Farmakologi Fakultas Kedokteran Universitas Brawijaya Malang \\ ****Laboratorium Mikrobiologi Fakultas Kedokteran Universitas Brawijaya Malang
}

\begin{abstract}
Malaria infection is still one of world health's problems that cause a high death rate $(20.9 \%$ - $50 \%)$. One of the reason is Plasmodium falciparum resist to conventional anti-malarial drugs. Neem seeds extract had been reported has antimalarial effect by decreasing parasitemia, but there has not been any report on its effect in inhibition hemazoin formation. The aim of this research was to find the effect of Neem seeds extract on parasitemia and hemazoin level in Plasmodium falciparum culture. Laboratory experiment was done by using Papua isolate of Plasmodium falciparum (2300) from NAMRU 2 Jakarta. After synchronized, malarial culture was divided into 4 groups namely Control group (culture medium only), Chloroquine group, Artemisinin group, and Neem seeds extracts group. Each treatment group was devided into 5 drug doses of $6.25 \mu / \mathrm{ml}, 12.5 \mu / \mathrm{ml}, 25 \mu / \mathrm{ml}, 50 \mu / \mathrm{ml}$ and $100 \mu / \mathrm{ml}$ respectively. Parasitemia was measured by Pyridine-hemochrome methods using spectrophotometer $\lambda 560 \mathrm{~nm}$. Statistical analysis was done involving one-wayANOVA followed by Tukey HSD and Pearson's Correlation. A significant difference was found between control and treatment groups in parasitemia and hemozoin level. Different dose in treatment groups didn't show any significant difference in both parasitemia $(p=0.99)$ and hemozoin level $(p=0.985)$. Tukey test between treatment groups didn't show a significant difference decrease of hemazoin level and parasitemia $(r=0.970)$. The conclusion was Neem deeds extract can inhibit $P$. falciparum growth by decreasing parasitemia and hemazoin level.
\end{abstract}

Key words: Neem seeds extract, parasitemia, hemazoin level, P. falciparum

\section{PENDAHULUAN}

Selama satu abad pemberantasan penyakit malaria, parasit penyebab malaria belum dapat dieliminasi secara total. Perhitungan secara kasar menunjukkan bahwa 120 juta orang menderita malaria dan 1 - 3 juta diantaranya meninggal (1). Di Indonesia hampir semua propinsi mempunyai daerah endemis malaria, walaupun tingkat endemisitasnya berbeda-beda. Daerah fokus malaria terbanyak berada di luar Jawa-Bali terutama di Indonesia Bagian Timur, sedangkan fokus di Jawa yaitu di Jawa Tengah, Daerah Istimewa Yogyakarta, Jawa Timur dan sepanjang pantai selatan di Jawa Barat (2). Berbagai upaya pemberantasan malaria telah dilakukan tetapi prevalensinya masih tetap tinggi. Hal ini disebabkan adanya berbagai hambatan dalam pemberantasan malaria diantaranya resistensi vektor terhadap insektisida dan Plasmodium falciparum (P.falciparum) menghasilkan galur baru yang resisten terhadap pengobatan konvensional (3).

Nimba (Azadirachta indica) merupakan tanaman asli Indonesia, dikenal sebagai tanaman obat yang mempunyai aktivitas biologi spektrum luas. Penelitian tentang zat aktif yang

Jurnal Kedokteran Brawijaya, Vol. XX, No.3, Desember 2004

Korespondensi: Noer Aini; Telp. 0341 - 470502 / 081555654070.

Email: noeraini2002@yahoo.com terdapat dalam Nimba mulai dilakukan sejak tahun 1942 oleh Siddiqui yang berhasil mengisolasi Nimbin dari minyak Nimba, kemudian lebih dari 135 komponen telah berhasil diisolasi dari berbagai bagian Nimba dan beberapa diantaranya sudah diketahui struktur kimianya. Komponen utama Nimba terdiri dari isoprenoid dan nonisoprenoid (4). Selama ini bagian Nimba yang banyak diteliti adalah daunnya, padahal pada biji Nimba juga terdapat beberapa zat aktif yang mempunyai aktivitas antimalaria (5). Ekstrak kasar biji Nimba dilaporkan efektif terhadap parasit malaria yang sensitif dan resisten Chloroquine $(6,7)$.

Penelitian lain menyatakan ekstrak dan purifikasi fraksi biji Nimba dapat menghambat pertumbuhan dan perkembangan stadium seksual dan aseksual P.falciparum yang sensitif dan resisten Chloroquine (8). Sampai saat ini penelitian tentang mekanisme kerja ekstrak biji Nimba dalam menurunkan parasit masih belum diketahui secara pasti, pada penelitian in vivo diduga berkaitan dengan respon imun.

Hemozoin adalah pigmen malaria yang terbentuk dari proses detoksifikasi heme. Proses detoksifikasi ini dilakukan Plasmodium setelah menyerap haemoglobin yang terdapat di eritrosit inang. Selama siklus intraerithrositik, P.falciparum menyerap $25-75 \% \mathrm{Hb}$ yang selanjutnya didegradasi didalam

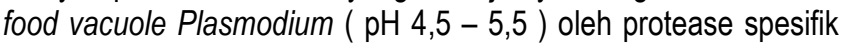
dan asam amino yang dihasilkan selanjutnya digunakan sebagai sintesa protein. Selama degradasi $\mathrm{Hb}$ akan dikeluarkan free heme yang bersifat sitotoksik bagi Plasmodium dan akan 
menyebabkan kerusakan membran Plasmodium (9). Pada P.falciparum salah satu cara detoksifikasi heme dicapai dengan cara polimerisasi free heme menjadi bentuk kristal yang insoluble yang dikenal sebagai hemozoin (pigmen malaria).

Hemozoin saat ini menjadi fokus penelitian obat anti malaria, karena mekanisme obat antimalaria yang selama ini bekerja dengan cara menghancurkan sintesa nucleoprotein melalui ikatan dengan DNA dan menghambat metabolisme folat mengalami resistensi terutama terhadap P.falciparum $(10,11)$. Obat anti malaria yang telah diketahui salah satu mekanisme kerjanya menghambat hemozoin adalah Chloroquine dan Artemisinin $(3,12)$. Nimba diketahui satu golongan dengan Artemisinin, yaitu Terpenoid, meskipun demikian selama ini belum ada penelitian ekstrak biji Nimba dalam menurunkan derajat parasit yang dihubungkan dengan penghambatan pembentukan hemozoin pada kultur P.falciparum.

Berdasarkan uraian diatas maka dilakukan penelitian tentang pengaruh ekstrak biji Nimba pada kultur P.falciparum dengan melihat pengaruhnya terhadap penurunan derajat parasit dan jumlah hemozoin.

\section{METODE}

Penelitian dilakukan di laboratorium Farmakologi dan laboratorium Biomedik Fakultas Kedokteran Universitas Brawijaya Malang pada bulan September 2003 - November 2004 dengan menggunakan P.falciparum isolat Papua (2300) dan biji Nimba yang diperoleh dari PAU ITB.

Penelitian ini merupakan penelitian eksperimen laboratorium dengan desain pre test dan post test untuk perhitungan parasit dan hemozoin dibandingkan dengan kontrol.

Setelah parasit $\geq 5 \%$ kultur malaria dibagi dalam 4 kelompok yaitu kelompok kontrol (hanya mengandung medium kultur dan pada perhitungan hemozoin diberi hemin chloride) kelompok Chloroquine, kelompok Artemisinin dan kelompok ekstrak biji Nimba yang masing-masing diberi 5 macam dosis (13). Setelah 48 jam parasit dihitung kembali dari sediaan hapusan darah tipis yang telah dipulas dengan pewarnaan giemsa. Jumlah parasit dihitung per 1000 eritrosit dengan mikroskop perbesaran 1000x. Hemozoin diukur dengan sphectrophotometer dengan panjang gelombang $560 \mathrm{~nm}$, selanjutnya akan dianalisis dengan uji statistika

\section{Ekstraksi dan Evaporasi biji Nimba (14)}

Biji nimba sejumlah $600 \mathrm{~g}$ dikeringkan kemudian dibersihkan, diblender sehingga diperoleh bentuk bubuk. Bubuk biji nimba ditimbang dengan neraca analitik, dan diperoleh hasil $300 \mathrm{~g}$. Kemudian diekstraksi dengan pelarut petroleum eter (b.p $40-60^{\circ} \mathrm{C}$ ). Ekstraksi dilakukan berulang-ulang sampai warna larutan ekstrak jernih homogen. Ampas dari hasil ekstraksi direndam dengan $\mathrm{CH}_{2} \mathrm{CL}_{2}$ (b.p $39,5^{\circ}$ - 40,52 $\mathrm{C}$ ). Kemudian dilakukan ekstraksi kembali seperti pada petroleum eter dengan menggunakan $\mathrm{CH}_{2} \mathrm{CL}_{2}$ sebagai pelarutnya. Selanjutnya diinkubasi selama 24 jam pada suhu ruangan, hasil yang diperoleh dipekatkan dengan rotary evaporator, ekstrak kasar dioven dan diperoleh hasil akhir ekstrak biji nimba dengan pelarut petroleum eter sebanyak 2,4813 g berupa cairan berwarna kekuningan dengan konsistensi seperti minyak.
Thawing dan kultur isolat P.falciparum galur Papua (2300) (15)

Isolat parasit diambil dari liquid Nitrogen Tank. Ditambahkan $\mathrm{NaCl} 12 \%, 1 / 5$ volume tetes demi tetes dengan spuit, ditunggu 5 menit. Kemudian ditambahkan $\mathrm{NaCl}$ 1,6 \% 9 kali volume tetes demi tetes dengan spuit, ditunggu 5 menit. Di centrifuge selama 5 menit dengan kecepatan $2000 \mathrm{rpm}$. Supernatan dibuang, pellet ditambahkan 0,9\% NaCl, 0,2\% glucosa, 9 kali volume, tetes demi tetes dengan spuit, ditunggu 5 menit. Di centrifuge kembali selama 5 menit dengan kecepatan 2000 rpm. Supernatan dibuang, ditambahkan medium RPMI yang mengandung $10 \%$ serum manusia type 0 dan $5 \%$ hematokrit dan dikultur dalam incubator $\mathrm{CO}_{2}$.

\section{Sinkronisasi Parasit (16)}

Digunakan larutan Sorbitol Great Culture $5 \%$. Suspensi eritrosit dimasukkan tabung centrifuge, dicentrifuge dengan kecepatan $1500 \mathrm{rpm}$ selama 5 menit dalam $4{ }^{\circ} \mathrm{C}$. Supernatan dibuang, packed cell ditambah dengan larutan sorbitol 5 kali volume, ditunggu 5- 10 menit pada temperatur kamar. Dicentrifuge kembali dengan kecepatan 1500 rpm selama 5 menit pada suhu $4{ }^{\circ} \mathrm{C}$. Supernatan dibuang, dicuci dengan medium lengkap ditambahkan $10 \%$ serum manusia 3 - 4 kali volume, diulangi 2 - 3 kali. Packed cell disuspensi dengan medium RPMI yang mengandung $10 \%$ serum manusia dan ditambahkan $50 \%$ eritrosit segar dan dibuat hematokrit $10 \%$. Diinkubasi dalam inkubator $\mathrm{CO}_{2}$ medium diganti setiap 24 jam.

\section{Tes obat in vitro}

Digunakan kultur pada stadium cincin dengan konsentrasi parasitemia $\geq 5 \%$. Kultur dipindahkan kedalam RPMI segar $(10 \%$ serum) sebelum penambahan obat. Ditambahkan Artemisinin, Chloroquine dan ekstrak biji Nimba dengan konsentrasi masingmasing $6,25 \mu \mathrm{g} / \mathrm{ml}, 12,5 \mu \mathrm{g} / \mathrm{ml}, 25 \mu \mathrm{g} / \mathrm{ml}, 50 \mu \mathrm{g} / \mathrm{ml}$, dan $100 \mu \mathrm{g} / \mathrm{ml}$, dicampur dengan cara inversi kemudian kultur dibagi kedalam wells. Selanjutnya kultur diamati sampai matur (48 jam).

\section{Perhitungan hemozoin (17)}

Kultur dipindahkan dari well 24 pada tabung centrifuge dan disentrifugasi. Ditambahkan Triton $X-100$ sampai konsentrasinya $1 \%$ (4 ml dari $2 \%$ Triton X-100 untuk $4 \mathrm{ml}$ kultur). Disisakan sedikit dari volume kultur untuk pewarnaan Giemsa $5 \%$ dan dihitung parasitemianya. Disentrifugasi kembali dengan kecepatan 13.000 rpm selama 45 menit (Beckman JA-20 rotor) pada suhu $4^{\circ} \mathrm{C}$. Supernatant dibuang dan pellet disimpan. Pellet disuspensi kembali dengan $1 \mathrm{ml}$ air distilasi dan dipindahkan ke tabung microcentrifuge sebanyak $1,5 \mathrm{ml}$. Disentrifugasi lagi dengan kecepatan $13.000 \mathrm{rpm}$ selama 15 menit dalam microcentrifuge, pada suhu $4^{\circ} \mathrm{C}$. Supernatant dibuang dan pellet disimpan. Membuat kurva standard, hemin diwakili dengan menggunakan ferriprotoporphyrin IX chloride (Sigma). Membuat larutan standar dengan cara mencampur larutan cadangan hemin pada DSMO dengan air distilasi. Diambil 520 $\mu$ lari larutan hemin standard dan dicampur dengan pellet hemozoin. Tube yang berisi kultur + pellet hemozoin ditambah 520 $\mu$ air distilasi + $62 \mu \mathrm{l} \mathrm{NaOH}$ dan $123 \mu$ pyridine (untuk $4 \mathrm{ml}$ sample). Setengah dari volume tersebut digunakan untuk sample. Tambahkan volume yang sama untuk larutan hemin standar. Campuran 
larutan tersebut dibagi sama banyak dalam 2 tube microsentrifuge. Ditambahkan $20 \mu \mathrm{l}$ dari $2,5 \mathrm{mM}$ Potassium Ferricyanide (K3Fe(CN)6) untuk satu tube haem oxida. Ditambahkan sedikit Sodium Hydrosulfite pada tube yang lain untuk reduksi haem. Dicampur dengan cara inversi. Selanjutnya diukur absorbance dengan spectrophotometer pada panjang gelombang $560 \mathrm{~nm}$. Dihitung jumlah hemozoin dengan standart hemin: OD560 = OD560 (reduce sample) - OD560 (oxidized sample). Dibandingkan antara hasil hemozoin kontrol, hemozoin
Artemisinin, hemozoin Choloroquine dan hemozoin ekstrak biji Nimba.

\section{Analisis Data}

Data yang diperoleh dianalisa dengan uji beda Anova antara rata-rata derajat parasit dengan jumlah hemozoin terhadap kelompok kontrol dan kelompok perlakuan. Selanjutnya untuk mengetahui signifikan perbedaan tiap-tiap kelompok perlakuan dilakukan uji Tukey pada taraf $5 \%$. Hubungan antara masingmasing variabel terikat diuji dengan uji korelasi Pearson.

\section{HASIL DAN ANALISIS DATA}

Tabel 1. Penurunan derajat Parasit pada Kontrol dan Kelompok Perlakuan

\begin{tabular}{|c|c|c|c|c|c|}
\hline \multirow{3}{*}{ Konsentrasi $(\mu \mathrm{g} / \mathrm{ml})$} & \multicolumn{4}{|c|}{ Parasit $\%$ ( rata-rata \pm S D) } & \multirow[b]{2}{*}{ Analisis Daté } \\
\hline & \multirow[b]{2}{*}{ Kontrol } & \multicolumn{3}{|c|}{ Kelompok Perlakuan } & \\
\hline & & Chloroquine & Artemisinin & Ekstrak biji Nimba & \multirow{3}{*}{$\begin{array}{l}{ }^{*} \text { UjiAnova } \\
p \leq 0,05\end{array}$} \\
\hline 6,25 & \multirow{5}{*}{$\begin{array}{c}8,59 \\
\pm 0,758\end{array}$} & $3,49 \pm 0,170$ & $3,48 \pm 0,257$ & $2,81 \pm 0,214$ & \\
\hline 12,5 & & $3,39 \pm 0,227$ & $2,87 \pm 0,228$ & $1,73 \pm 0,290$ & \\
\hline 25 & & $2,29 \pm 0,135$ & $2,22 \pm 0,205$ & $1,46 \pm 0,118$ & \multirow{3}{*}{$\begin{array}{l}{ }^{*} \text { UjiTukey } \\
p \geq 0,05\end{array}$} \\
\hline 50 & & $1,31 \pm 0,144$ & $1,71 \pm 0,312$ & $1,34 \pm 0,067$ & \\
\hline 100 & & $1,23 \pm 0,095$ & $1,40 \pm 0,145$ & $1,21 \pm 0,070$ & \\
\hline
\end{tabular}

Keterangan:

*Uji Anova: terdapat perbedaan yang signifikan antara kontrol dan kelompok perlakuan terhadap penurunan derajat parasit $(p=0.0001)$.

Pemberian konsentrasi yang berbeda tidak menunjukkan perbedaan signifikan terhadap penurunan derajat parasit $(p=0.99)$

** Uji Tukey: diantara kelompok perlakuan tidak menunjukkan perbedaan signifikan terhadap penurunan derajat parasit.

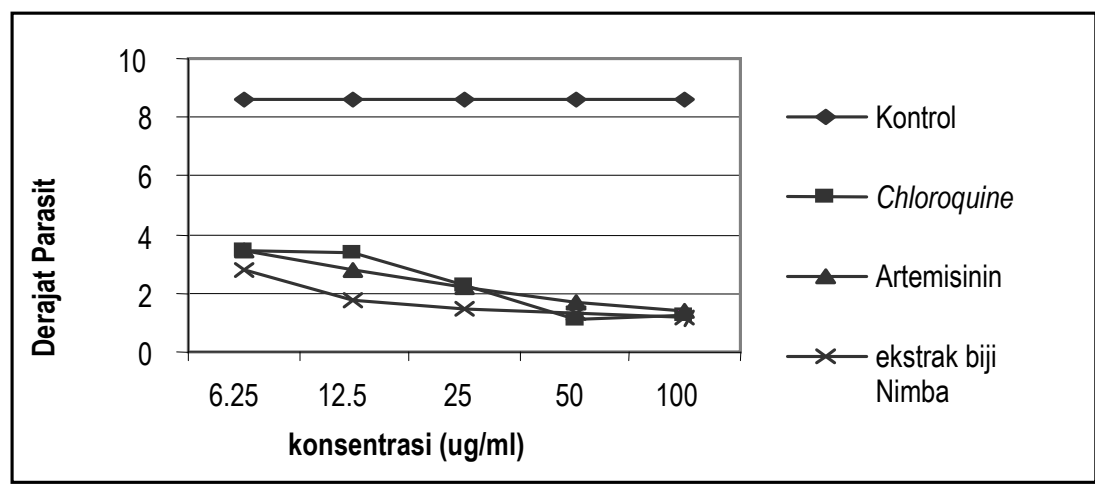

Gambar 1. Kurva penurunan derajat parasit pada kontrol dan kelompok perlakuan. Tampak penurunan derajat parasit yang signifikan pada kelompok perlakuan.

Dari uji Tukey diperoleh hasil adanya perbedaan signifikan $(p=0,000)$ antara kontrol dengan kelompok perlakuan terhadap penurunan derajat parasit. Sedangkan perlakuan pemberian obat yang berbeda tidak memberikan hasil perbedaan yang signifikan terhadap penurunan derajat parasit dengan nilai $p=0,998$ untuk
Chloroquine dan Artemisinin, $p=0,883$ untuk Chloroquine dan ekstrak biji Nimba, dan $p=0,945$ untuk Artemisinin dan ekstrak biji Nimba. 


\section{Analisis Regresi Parasit.}

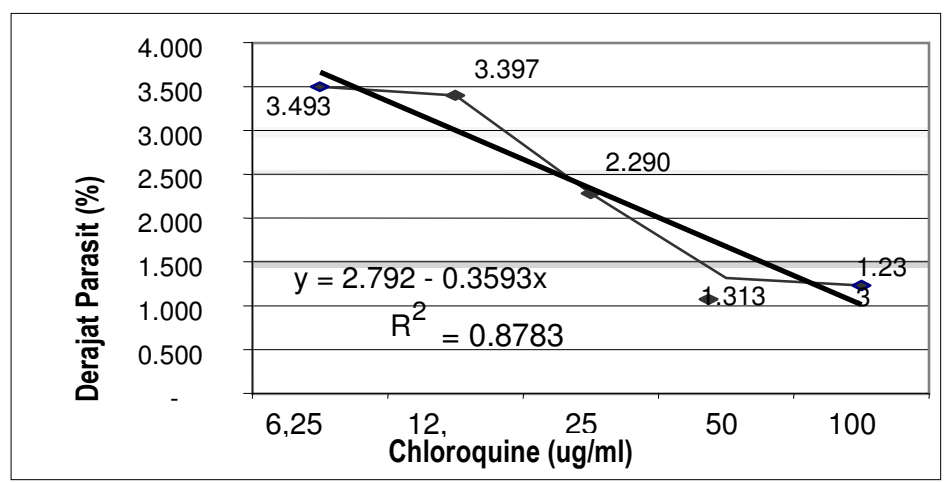

Gambar 2. Kurva regresi Chloroquine dengan derajat parasit.

Tampak hubungan terbalik antara peningkatan konsentrasi Chloroquine dengan penurunan derajat parasit.

Pada uji regresi diperoleh hasil penurunan derajat parasit yang signifikan $(p=0,000)$ dengan nilai $\mathrm{R}^{2}=87,83 \%$ dan didapatkan persamaan parasit $=2,792-0,3593 \mathrm{X}$, ini berarti bahwa setiap peningkatan konsentrasi Chloroquine sebesar 1 $\mu \mathrm{g} / \mathrm{ml}$ akan menurunkan derajat parasit sebesar 0,3593 kali.

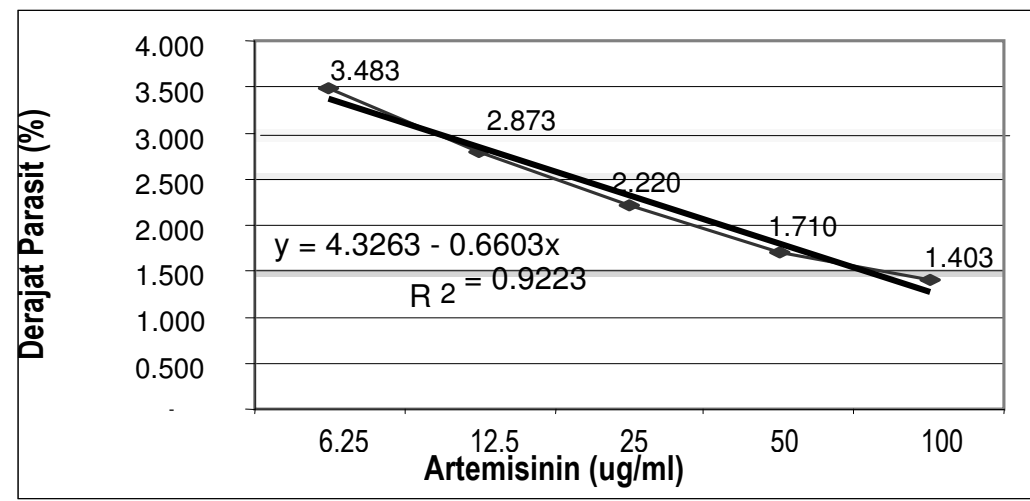

Gambar 3. Kurva regresi Artemisinin dengan derajat parasit.

Tampak hubungan terbalik antara peningkatan konsentrasi Artemisinin dengan penurunan parasit.

Pada uji regresi diperoleh hasil penurunan derajat parasit yang signifikan $(p=0,000)$ dengan nilai $R^{2}=92,23 \%$ dan didapatkan persamaan parasit $=4,3263-0,6603 \mathrm{X}$, Ini berarti bahwa setiap peningkatan konsentrasi Artemisinin sebesar 1 $\mu \mathrm{g} / \mathrm{ml}$ akan menurunkan derajat parasit sebesar 0,6603 kali.

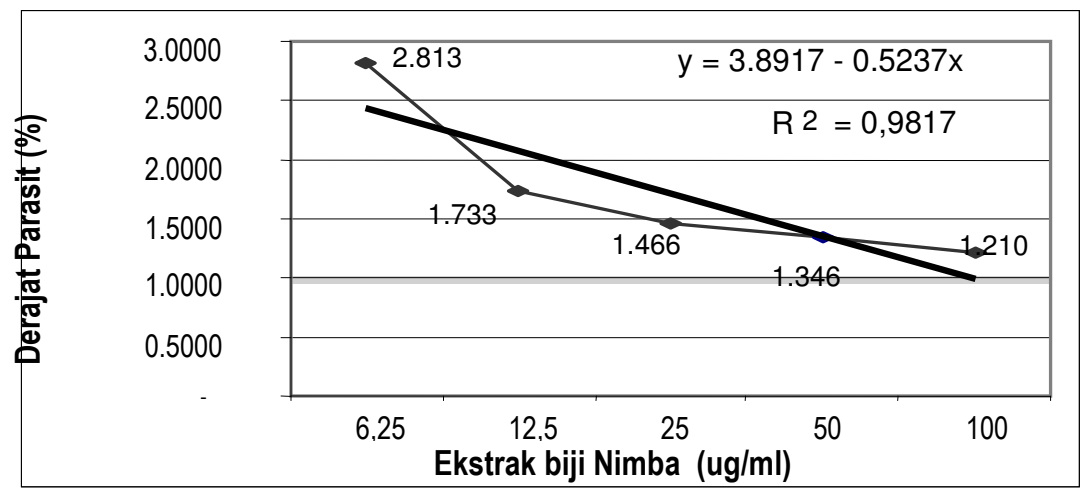

Gambar 4. Kurva regresi ekstrak biji Nimba dengan derajat parasit.

Tampak hubungan terbalik antara peningkatan konsentrasi ekstrak biji Nimba dengan penurunan derajat parasit. 
Pada uji regresi diperoleh hasil penurunan parasit yang signifikan $(p=0,000)$ dengan nilai $R^{2}=98,17 \%$ dan didapatkan persamaan parasit $=3,8917-0,5237 \mathrm{X}$ ini berarti bahwa setiap peningkatan konsentrasi ekstrak biji Nimba sebesar $1 \mu \mathrm{g} / \mathrm{ml}$ akan menurunkan parasit sebesar 0,5237 kali.

\section{Hemozoin}

Tabel 2. Penurunan hemozoin pada Kontrol dan kelompok Perlakuan

\begin{tabular}{|c|c|c|c|c|c|}
\hline \multirow{3}{*}{ Konsentrasi $(\mu \mathrm{g} / \mathrm{ml})$} & \multicolumn{4}{|c|}{ Hemozoin $(\mathrm{nm})$ ( rata-rata \pm S D) } & \multirow[b]{2}{*}{ Analisis Data } \\
\hline & \multirow[b]{2}{*}{ Kontrol } & \multicolumn{3}{|c|}{ Kelompok Perlakuan } & \\
\hline & & Chloroquine & Artemisinin & Ekstrak biji Nimba & \multirow{6}{*}{$\begin{array}{l}{ }^{*} \text { Uji Anova } \\
p \leq 0,05 \\
{ }^{* *} \text { UjiTukey } \\
p \geq 0,05\end{array}$} \\
\hline 6,25 & \multirow{5}{*}{$0.0090 \pm 0,0010$} & $0.0050 \pm 0.0010$ & $0.0052 \pm 0.00171$ & $0.0036 \pm 0.00076$ & \\
\hline 12,5 & & $0.0050 \pm 0.0011$ & $0.0040 \pm 0.00100$ & $0.0020 \pm 0.00011$ & \\
\hline 25 & & $0.0040 \pm 0.0002$ & $0.0030 \pm 0.00050$ & $0.0016 \pm 0.00115$ & \\
\hline 50 & & $0.0030 \pm 0.0010$ & $0.0022 \pm 0.00034$ & $0.0011 \pm 0.00028$ & \\
\hline 100 & & $0.0030 \pm 0.0005$ & $0.0020 \pm 0.00050$ & $0.0010 \pm 0.00011$ & \\
\hline
\end{tabular}

Keterangan:

*Uji Anova:

terdapat perbedaan signifikan antara kontrol dan kelompok perlakuan terhadap jumlah hemozoin $(p=0,000)$. Pemberian konsentrasi yang berbeda tidak menunjukkan perbedaan yang signifikan terhadap jumlah hemozoin $(p=0,98)$

** Uji Tukey: diantara kelompok perlakuan tidak menunjukkan perbedaan yang signifikan terhadap jumlah hemozoin.

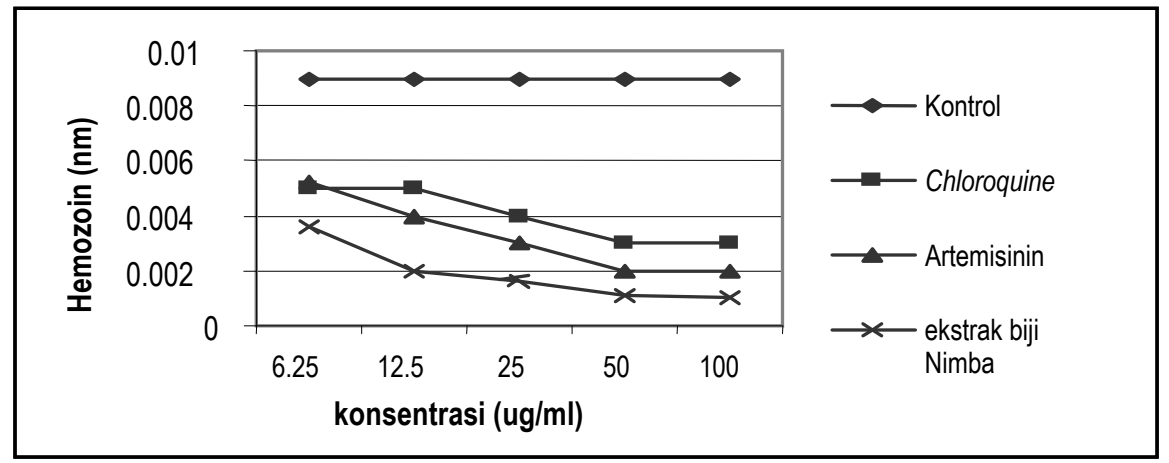

Gambar 5. Kurva jumlah hemozoin pada Kontrol dan kelompok Perlakuan.

Tampak penurunan hemozoin yang signifikan pada KelompokPerlakuan

Dari uji Tukey diperoleh hasil adanya perbedaan signifikan antara kontrol dengan kelompok perlakuan dengan nilai $p=0,004$ untuk kontrol dengan Chloroquine, $p=0,001$ untuk kontrol dengan Artemisinin, $p=0,000$ untuk kontrol dengan ekstrak biji Nimba. Sedangkan perlakuan pemberian obat yang berbeda tidak memberikan perbedaan yang signifikan terhadap jumlah hemozoin dengan nilai $p=0,912$ untuk Chloroquine dan Artemisinin, $p=0,395$ untuk Chloroquine dan ekstrak biji Nimba, $p$ $=0,762$ untuk Artemisinin dan ekstrak biji Nimba.

\section{Analisis Regresi Hemozoin}

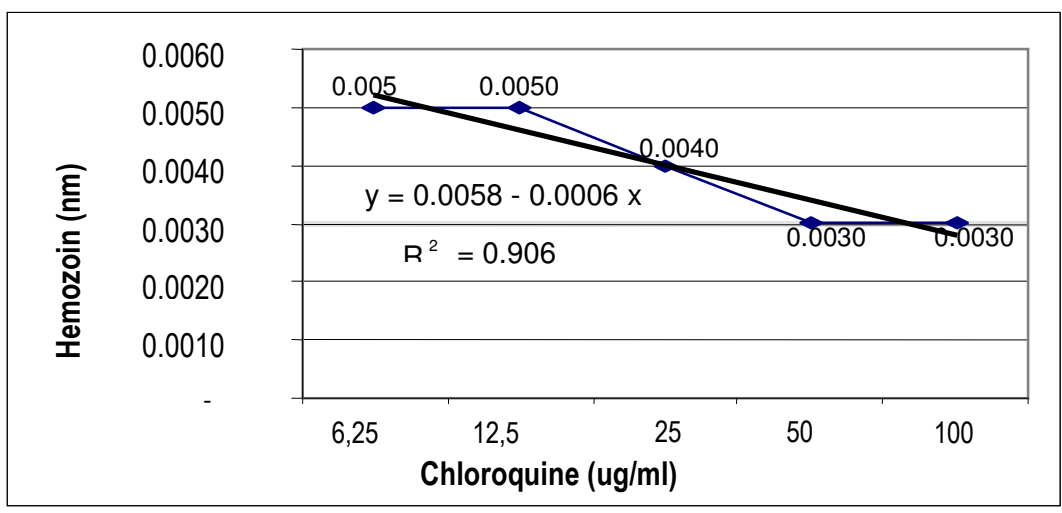

Gambar 6. Kurva regresi Chloroquine dengan hemozoin.

Tampak hubungan terbalik antara peningkatan konsentrasi Chloroquine dengan penurunan hemozoin 
Pada uji regresi diperoleh hasil penurunan hemozoin yang signifikan $(p=0,000)$ dengan nilai $R^{2}=90,6 \%$ dan didapatkan persamaan hemozoin $=0,0058-0,0006 \mathrm{X}$ ini berarti bahwa setiap peningkatan konsentrasi Chloroquine sebesar $1 \mu \mathrm{g} / \mathrm{ml}$ akan menurunkan hemozoin sebesar 0,0006 kali.

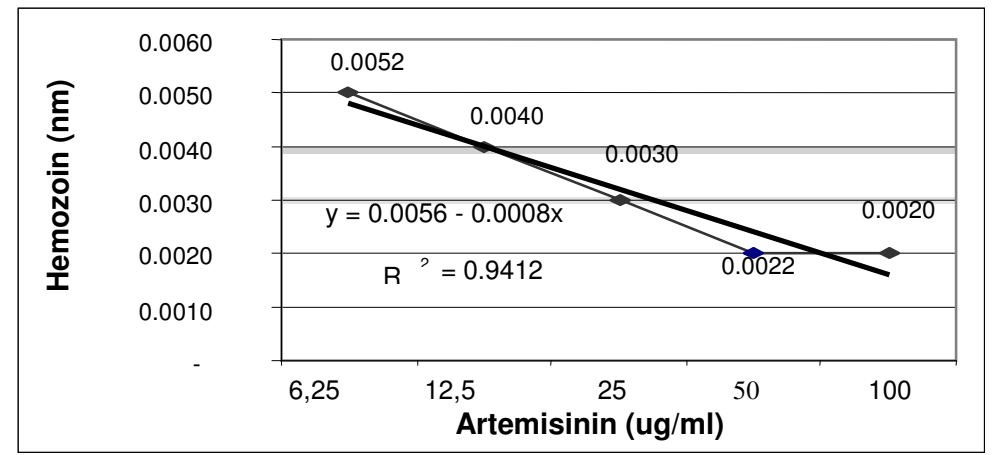

Gambar 7. Kurva regresi Artemisinin dengan emoción.

Tampak hubungan terbalik antara peningkatan konsentrasi Artemisinin dengan penurunan hemozoin.

Pada uji regresi diperoleh hasil penurunan hemozoin yang signifikan $(p=0,000)$ dengan nilai $R^{2}=94,12 \%$ dan didapatkan persamaan hemozoin $=0,0056-0,0008 \mathrm{X}$ ini berarti bahwa setiap peningkatan konsentrasi Artemisinin sebesar $1 \mu \mathrm{g} / \mathrm{ml}$ akan menurunkan hemozoin sebesar 0,0008 kali.

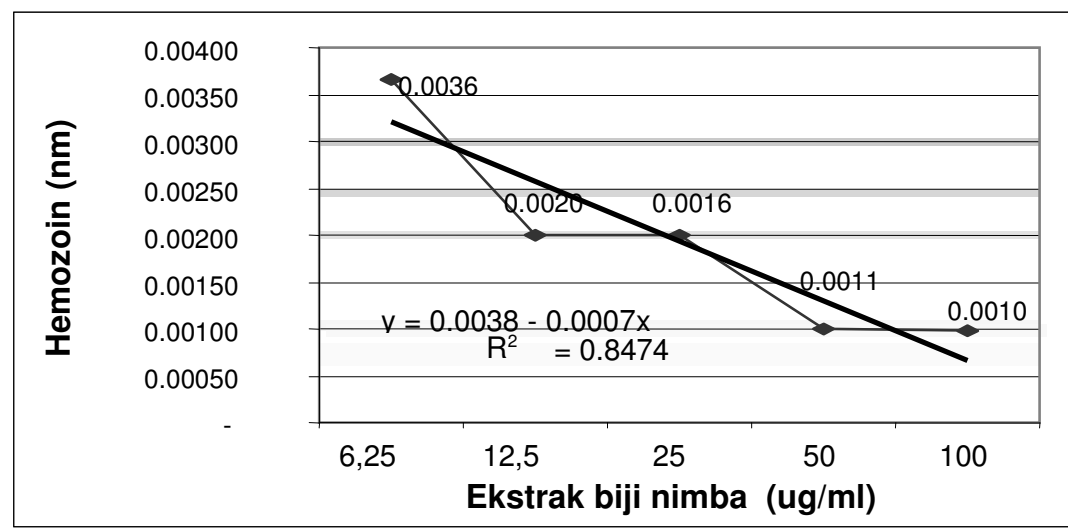

Gambar 8. Kurva regresi ekstrak biji Nimba dengan hemozoin.

Tampak hubungan terbalik antara peningkatan konsentrasi Ekstrak biji Nimba dengan penurunan hemozoin.

Pada uji regresi diperoleh hasil penurunan hemozoin yang signifikan $(p=0,000)$ dengan nilai $R^{2}=84,74 \%$, dan didapatkan persamaan hemozoin $=0,0038-0,0007 \mathrm{X}$, ini berarti bahwa setiap peningkatan konsentrasi ekstrak biji Nimba sebesar 1 $\mu \mathrm{g} / \mathrm{ml}$ akan menurunkan hemozoin sebesar 0,0007 kali.

\section{Uji Korelasi Pearson}

Untuk mengetahui adanya hubungan antara penurunan jumlah hemozoin dengan penurunan derajat parasit pada kelompok perlakuan dilakukan uji Korelasi Pearson. 


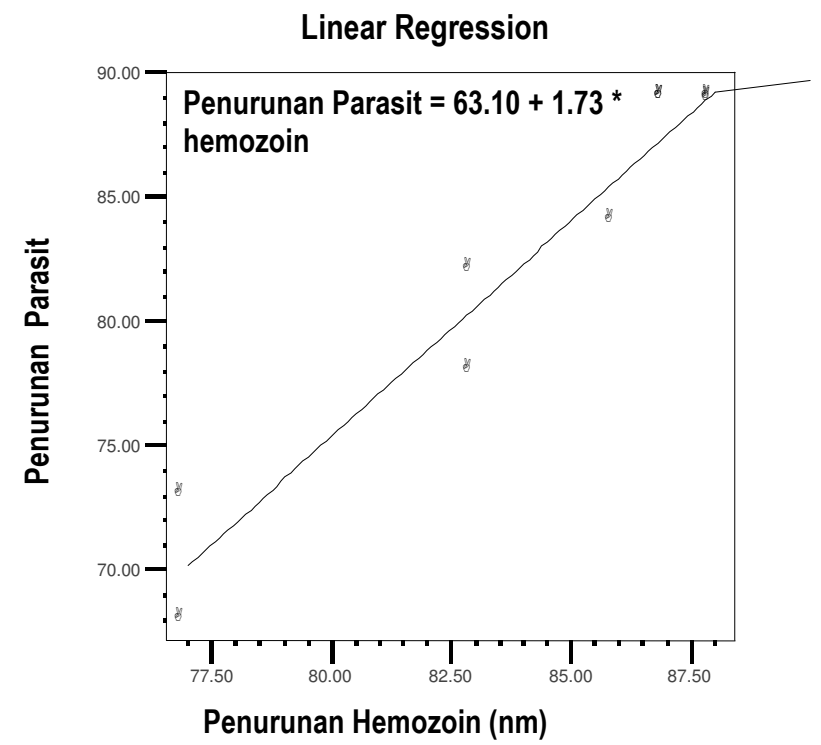

Gambar 9. Scatter plot yang menunjukkan hubungan antara penurunan jumlah Hemozoin dengan penurunan derajat Parasit.

Pada analisis korelasi Pearson didapatkan korelasi positif yang kuat dan signifikan $(r=0,84, p=0,000)$ dan pada analisis regresi didapatkan persamaan penurunan parasit $=63,10+1,73$ hemozoin dengan nilai $R=0,94$. Ini berarti setiap penurunan hemozoin $1 \mathrm{~nm}$ akan menurunkan parasit sebesar 1,73 kali.

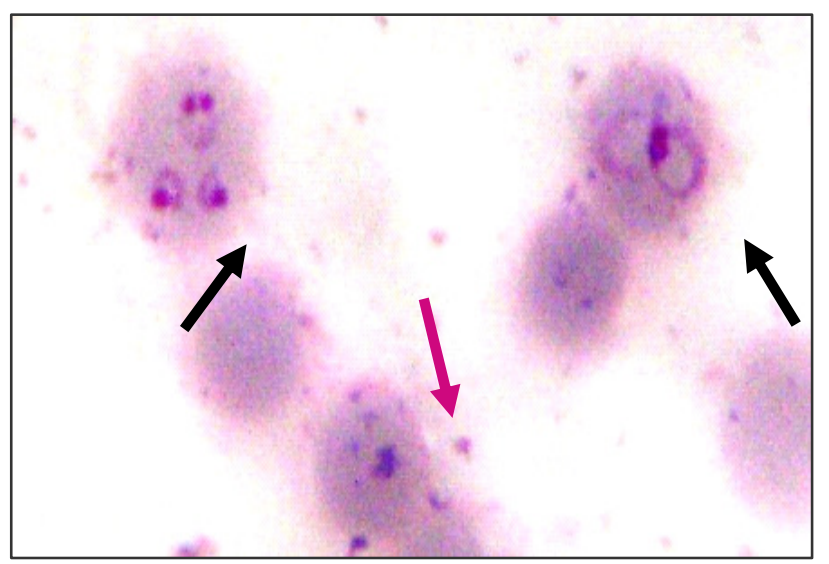

Gambar 10.Proses thawing pada kultur P.falciparum (ring form dan schizont)

Panah hitam : eritrosit terinfeksi P.falciparum stadium ring form

Panah merah: eritrosit terinfeksi P.falciparum stadium schizont (pemulasan Giemsa, pembesaran 1000 x)

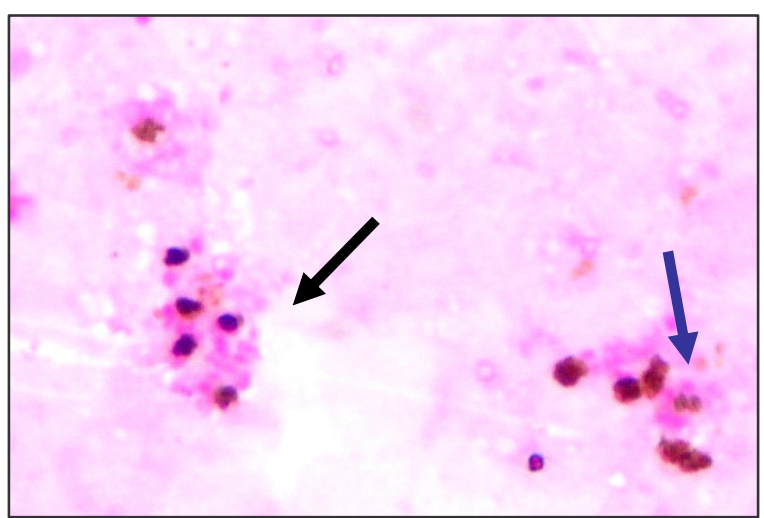

Gambar 11. Proses sinkronisasi pada kultur P.falciparum

Panah hitam : eritrosit terinfeksi P.falciparum stadium schizont

Panah biru : hemozoin (pemulasan Giemsa, pembesaran $1000 \mathrm{x}$ )

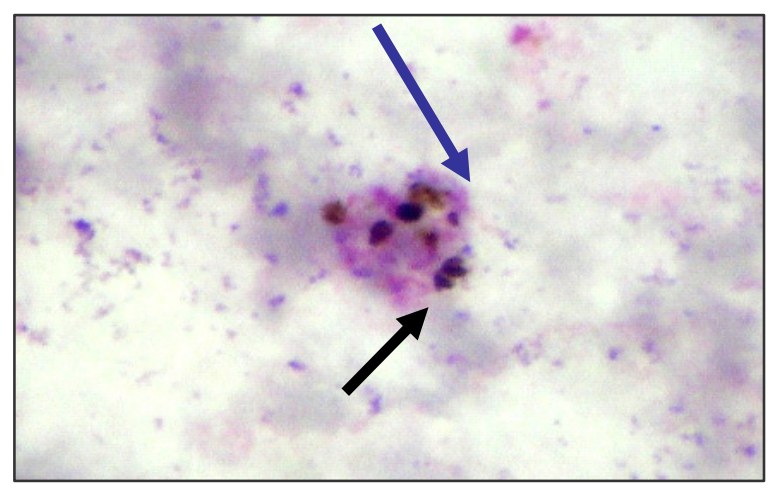

Gambar 12. Proses sinkronisasi pada kultur P.falciparum

Panah hitam : eritrosit terinfeksi P.falciparum stadium schizont, Panah biru : hemozoin yang berwarna hijau kecoklatan (pemulasan Giemsa, pembesaran $1000 \mathrm{x}$ ) 


\section{DISKUSI}

\section{Derajat Parasit}

Hasil uji ANOVA didapatkan penurunan derajat parasit yang signifikan $(p=0,000)$ antara kelompok kontrol dan kelompok perlakuan (Chloroquine, Artemisinin dan ekstrak biji Nimba). Pada kelompok Chloroquine hal ini berkaitan dengan mekanisme kerja Chloroquine menurunkan derajat parasit melalui kemampuan menghalangi sintesa enzim parasit dalam pembentukan DNA dan RNA sehingga proses pembelahan terganggu, selain itu Chloroquine berikatan dengan heme yang akan menghambat pembentukan hemozoin, sehingga heme tetap terakumulasi dalam bentuk free heme yang bersifat toksik dan mengakibatkan kematian Plasmodium $(3,9,18,19,20)$.

Artemisinin diketahui mempunyai struktur molekul yang mengandung jembatan peroksida (peroxide bridge), mekanisme kerja Artemisinin menurunkan derajat parasit sangat berkaitan dengan struktur molekulnya yang pada proses digesti haemoglobin diputus oleh ion $\mathrm{Fe}^{2+}$ menjadi radikal bebas yang sangat reaktif. Radikal-radikal Artemisinin ini kemudian menghambat dan memodifikasi berbagai macam molekul dalam Plasmodium yang mengakibatkan Plasmodium tersebut mati $(12,21)$. Penelitian lain menjelaskan mekanisme kerja Artemisinin melalui penghambatan enzim the malarial calsium-dependent ATP ase (PfATP6) yang terletak dalam kompartemen intrasel terbungkus membran yang disebut retikulum endoplasma. Pada Plasmodium, kompartemen ini tersebar luas dalam sitoplasma di luar food vacuole. Radikal bebas yang dihasilkan Artemisinin mengikat dan menghambat PfATP6 secara ireversibel dan spesifik sehingga mengakibatkan pertumbuhan parasit terhambat. (22).

Pada penelitian ini kemampuan ekstrak biji Nimba menurunkan derajat parasit secara signifikan diduga karena adanya beberapa zat aktif dalam biji Nimba yang mempunyai aktifitas antimalaria seperti Azadirachtin, Nimbolide $(7,13,23,24,25,26)$.

Pemberian konsentrasi yang berbeda pada kelompok perlakuan tidak menunjukkan perbedaan signifikan dalam menurunkan derajat parasit ( $p=0.99$ ), hal ini disebabkan karena dosis masing-masing konsentrasi terlalu besar, disamping itu dosis konsentrasi awal perlu diperkecil atau diturunkan.

Hasil uji Tukey diantara kelompok perlakuan terhadap penurunan derajat parasit tidak terdapat perbedaan yang signifikan ( $p \geq 0,05$ ), tetapi jika dilihat dari kurva penurunan derajat parasit pada kontrol dan kelompok perlakuan tampak kecenderungan kelompok ekstrak biji Nimba lebih kuat menurunkan derajat parasit dibandingkan dengan kelompok Chloroquine dan Artemisinin, begitu juga dilihat dari data deskriptif, penurunan derajat parasit pada kelompok ekstrak biji Nimba paling optimal dicapai pada konsentrasi $25 \mu \mathrm{g} / \mathrm{ml}(1,46 \pm$ $0,118)$ karena dengan penambahan konsentrasi yang lebih besar $(50 \mu \mathrm{g} / \mathrm{ml}$ dan $100 \mu \mathrm{g} / \mathrm{ml})$ hasil penurunan derajat parasit tidak jauh berbeda $(1,34 \pm 0,067$ dan 1,21 $\pm 0,070)$, sedangkan pada kelompok Chloroquine dan Artemisinin untuk penurunan derajat parasit yang optimal dicapai pada konsentrasi $50 \mu \mathrm{g} / \mathrm{ml}$ (Chloroquine 1,31 $\pm 0,144$ Artemisinin 1,71 $\pm 0,312$ ). Hasil uji regresi juga menunjukkan perbedaan respon penurunan derajat parasit terhadap peningkatan konsentrasi obat diantara kelompok perlakuan. Respon paling rendah ternyata pada kelompok
Chloroquine $(0,3593)$, pada kelompok Artemisinin $(0,6603)$ dan pada kelompok ekstrak biji Nimba $(0,5237)$. Hal ini menunjukkan bahwa kecenderungan kemampuan ekstrak biji Nimba menurunkan derajat parasit lebih baik dari Chloroquine walaupun tidak mencapai keefektifan seperti Artemisinin.

\section{Hemozoin}

Hasil uji ANOVA antara kelompok kontrol dan kelompok perlakuan didapatkan penurunan jumlah hemozoin yang signifikan $(p=0,000)$. Hal ini membuktikan bahwa salah satu mekanisme kerja Chloroquine dan Artemisinin adalah menghambat pembentukan hemozoin. (3,9,12,18,20,21,22). Kemampuan Chloroquine secara selektif terakumulasi dalam food vacuole Plasmodium melalui mekanisme (i) protonation dan ion trapping disebabkan karena $\mathrm{pH}$ yang lebih rendah dalam food vacuole, (ii) pengambilan aktif Chloroquine oleh parasite transporter (CDR dan MDR1) dan (iii) ikatan Chloroquine dengan reseptor spesifik dalam food vacuole. Didalam food vacuole Plasmodium, Chloroquine akan menghambat pembentukan hemozoin dari heme yang berasal dari penyerapan hemoglobin, free heme akan menyebabkan kerusakan membran dan menyebabkan kematian parasit (27). Hemozoin merupakan polimer heme yang berkaitan dengan sensitifitas Artemisinin, hal ini ditunjukkan pada penelitian yang dilakukan terhadap $\mathrm{RC}$ strain P.berghei, didapatkan hasil bahwa Artemisinin tidak aktif disebabkan karena kurangnya kadar hemozoin yang terdapat pada RC strain P.berghei (28). Artemisinin mampu menghambat biosintesis hemozoin, pada penelitian yang dilakukan terhadap cel free condition pada konsentrasi mikro molar $(\mu \mathrm{M})$ mampu menghambat pembentukan hemozoin (3).

Pada penelitian ini ekstrak biji Nimba terbukti mampu menurunkan jumlah hemozoin secara signifikan. Meskipun mekanisme ekstrak biji Nimba menghambat pembentukan hemozoin belum diketahui secara pasti melalui polimerisasi heme seperti Chloroquine atau berinteraksi dengan heme seperti Artemisinin, diduga karena kemiripan struktur kimia zat aktif yang terdapat didalam Artemisinin (sesquiterpen lactone) dan ekstrak biji Nimba (triterpenoid).

Hasil uji Tukey diantara kelompok perlakuan terhadap penurunan jumlah hemozoin, tidak didapatkan perbedaan yang signifikan ( $p \geq 0,05$ ). Pada kurva hemozoin tampak penurunan jumlah hemozoin paling optimal dicapai semua kelompok perlakuan pada konsentrasi $50 \mu \mathrm{g} / \mathrm{ml}$, tetapi hasil uji regresi menunjukkan perbedaan respon penurunan jumlah hemozoin terhadap peningkatan konsentrasi obat diantara kelompok perlakuan. Respon paling rendah pada kelompokChloroquine $(0,0006)$, pada kelompok Artemisinin $(0,0008)$ dan pada kelompok ekstrak biji Nimba (0,0007). Hal ini menunjukkan kecenderungan bahwa kemampuan ekstrak biji Nimba menurunkan jumlah hemozoin lebih baik dari Chloroquine walaupun tidak mencapai keefektifan seperti Artemisinin.

Peranan penting hemozoin dalam penelitian obat malaria dilakukan dengan pengukuran secara kualitatif dan kuantitatif. Ada beberapa metode yang lazim digunakan untuk mengukur hemozoin yaitu Spectroscopy (untuk melihat phagocytosis eritrosit dan hemozoin), spectrophotometric (spesifik untuk hemozoin yang berasal dari heme tetapi kurang sensitif), dan fluorescence (untuk mendeteksi hemozoin yang terdapat di jaringan). 
Pada penelitian ini metode yang digunakan adalah pyridine haemochrome assay. Metode ini memang dipakai untuk melihat mekanisme kerja obat, karena lebih sensitif dibandingkan dengan metode yang lain dan mudah dilakukan tetapi prosesnya harus dilakukan secara cepat karena sifat pyridine yang toksik dan tidak stabil $(9,18,29)$. Meskipun demikian masih ada kendala yang menyertai pengukuran hemozoin pada penelitian ini, beberapa jurnal menyebutkan bahwa pengukuran hemozoin sering gagal disebabkan karena sifat pellet hemozoin yang menempel pada bahan plastik sehingga mempengaruhi keakuratan pengukuran, oleh karena itu alat yang digunakan untuk mengukur hemozoin sebaiknya non pyrogen, kemungkinan faktor inilah yang diduga menyebabkan tidak adanya perbedaan signifikan jumlah hemozoin pada kelompok perlakuan.

\section{Korelasi antara penurunan jumlah hemozoin dengan penurunan derajat parasit}

Hasil uji korelasi Pearson didapatkan korelasi positif yang kuat dan signifikan $(r=0,970, p=0,000)$ antara penurunan jumlah hemozoin dengan penurunan derajat parasit. Korelasi positif berarti apabila jumlah hemozoin menurun maka derajat parasit menurun, jumlah hemozoin meningkat maka derajat parasit akan meningkat pula. Seperti diketahui fungsi hemozoin untuk mencegah kerusakan parasit dari oxygen radikal atau mengantisipasi perubahan fungsi dari oksigen bebas terhadap kemungkinan kerusakan parasit. Pembentukan hemozoin pada dasarnya mengubah kandungan reaktif Fe pada proses oksidasi dan lingkungan asam didalam food vacuole parasit dimana hemoglobin didegradasi. Radikal oksigen bebas berupa superoxide (02-), peroxida ( $\mathrm{O}^{2-}$ ) dan radikal hidroksi ( $\left.\mathrm{HO}^{-}\right)$dapat meningkatkan penghancuran terhadap makromolekul seluler dan lipid. Radikal O2 bersama-sama dengan iNOS dapat melakukan oksidasi phagosit yang didalam acidic phagosome menghasilkan radikal peroksinitrit sangat reaktif yang dapat membunuh parasit. (30).

Dengan jumlah hemozoin yang meningkat diasumsikan Plasmodium dapat melakukan proses detoksifikasi heme dengan baik sehingga Plasmodium tetap hidup (derajat parasit meningkat). Hal ini sesuai dengan penelitian sebelumnya (pada hewan coba) yang menyebutkan bahwa pada jaringan yang ditemukan jumlah hemozoin yang tinggi ternyata didapatkan derajat parasit tinggi juga $(18,31)$. Keterkaitan hemozoin dengan parasitemia menarik peneliti untuk mengungkap peran hemozoin, beberapa peneliti menyatakan bahwa hemozoin yang terdapat dalam leucocyte (neutrophil dan monocyte) dapat dijadikan indikator prognostic penyakit. Seperti yang diteliti oleh Amadu et al.,1998 pada penderita malaria asimptomatik, malaria tanpa komplikasi, dan malaria serebral ditemukan hemozoin yang terdapat dalam neutrofil meningkat dari $7 \%, 9 \%$, dan $27 \%$ (32). Penelitian pada 146 anak Nigerian yang menderita malaria, ditemukan lebih dari $90 \%$ hemozoin terdapat pada neutrophil dan monocyte (32). Metzger et al., tahun 1995 meneliti 104 penderita malaria yang dirawat di RS, didapatkan $83 \%$ hemozoin dalam monocyte dan 53 \% hemozoin dalam neutrophil (33). Pada kasus malaria serebral dimana pemeriksaan hapusan darah (smear) negatif, jumlah hemozoin dalam monocyte dapat digunakan sebagai indikator peningkatan derajat parasit (high grade parasitemia) (27).

\section{KESIMPULAN}

1. Ekstrak biji Nimba dapat menurunkan derajat parasit dan jumlah hemozoin pada kultur P.falciparum.

2. Pada konsentrasi $25 \mu \mathrm{g} / \mathrm{ml}$ ekstrak biji Nimba menurunkan derajat parasit secara optimal, sedangkan penurunan jumlah hemozoin secara optimal dicapai pada konsentrasi $50 \mu \mathrm{g} / \mathrm{ml}$.

3. Kemampuan ekstrak biji Nimba menurunkan derajat parasit dan jumlah hemozoin pada kultur $P$.falciparum lebih baik dari Chloroquine walaupun tidak mencapai keefektifan seperti Artemisinin.

4. Terdapat hubungan yang kuat antara penurunan jumlah hemozoin dengan penurunan derajat parasit pada kultur P.falciparum.

\section{SARAN}

1. Kemampuan ekstrak biji Nimba menurunkan derajat parasit diduga karena adanya zat aktif yang mempunyai efek anti malaria yaitu azadirachtin, nimbolide dan gedunin, perlu penelitian lebih lanjut tentang farmakokinetik dan farmakodinamik zat aktif tersebut

2. Perlu dilakukan penelitian uji toksisitas ekstrak biji Nimba pada hewan coba.

3. Penelitian lebih lanjut untuk memperjelas mekanisme kerja ekstrak biji Nimba dalam menghambat pembentukan hemozoin pada kultur P.falciparum.

\section{DAFTAR KEPUSTAKAAN}

1. Schneider EL, Carlson HK, Chang HH. Heme Detoxification In P. falciparum. Berkeley:The Marletta Lab. University of California; 2003.

2. Trijoko. Pemberian Ekstrak Daun Mimba (Azadirachta indica) Pada Mencit Yang Terinfeksi Plasmodium berghei. [Thesis]. Yogyakarta: UGM. 1995.

3. Pandey AV and Chauhan VS. Heme Polymerization by Malarial Parasit: A Potensial Target For Antimalarial Drug Development. India: International Centre for Genetic Engineering and Biotechnology; 2000.

4. Biswas K, Chatyopadhya I, Baherjee RK, and Bandyopadhyay U. Biological Activities And Medicinal Properties Of Neem (Azadirachta indica). Current Science 2002; 82 (11).

5. Khosla P, Bhanwra S, Singh J, Seth S and Srivastava RK. A Study Of Hypoglycaemic Effect Of A.Indica (Neem) In Normal And Alloxan Diabetic Rabbits. Indian Journal Physiol.Pharmacol; 2000; 44: 69-74.

6. Badani L, Deolankar RP, Kulkarni MM, Nagsampgi BA and Wagh UV. Indian Journal Malariology 1987.

7. Khalid SA, Duddeck H, Gonzales- Sierra H. Isolation And Characterization Of An Antimalarial Agent Of The Neem Tree Azadirachta indica. PubMed; 1989; 922-926. 
8. Dhar R, Zhang K, Talwar GP, Garg S and Srivastava RK. Journal Ethnopharmacol 1989; 61: 31-33.

9. Meshnick SR. Artemisinin And The Anti Malarial Endoperoxides, From Herbal Remedy To Targeted Chemotherapy. Microbiology Review; 1996; 60: 301-315.

10. Harijanto PN. Malaria, Epidemiologi, Patogenesis, Manifestasi Klinik \& Penanganannya. Jakarta: EGC; 2000.

11. Lombardini. Antiparasitic Drugs-The Chemotherapy of Malaria. 2003.

12. Hoon LJ. Artemisinin \& Its Derivatives For Antimalarial Agents. 2000. synmed.snu.ac,kr/courses/graduate/di

13. Bickii J, Njifutie N, Foyere JA, Basco LK, Ringwald P. In Vitro Antimalarial Activity Of Limonoids From Khyagrandifoliola (meliaceae). Journal Ethnopharmacol 2000.

14. Castellanos L, Correa RS, Martinez E, and Calderon JS. Oleanane Triterpenoids From Cedrela Montana (Meliaceae). J. Znaturforsch 2002: 575-578.

15. Tantular IS, Suhintom P, Hidajati BS, Dachlan P. Biakan Berkesenambungan Plasmodium falciparum Stodium Eritrosit. Jurnal Biologi Molekuler Kedokteran; 2000; 99-111.

16. Lambros C, Vanderberg JP. Synchronization of Plasmodium falciparum Erythrocytic Stages In Culture. J. Parasitology 1976; 65: $418-420$.

17. Schlichtherle M, Wahlgren M, Perlmann H, Scharf A. Methods In Malaria Research. Third Edition. MR4/ATCC, Manassas Virginia; 2000; 32-33

18. Sullivan DJ, Gluzman llya Y, Russell DG and Goldberg DE. On The Molecular Mechanism Of Chloroquine's Antimalarial Action. Medical sciences, 1996; 93: $11865-11870$.

19. Rosenthal PJ and Mesnick SR. Hemoglobin Catabolism And Iron Utilization By Malaria Parasites. Molecular and Biochemical Parasitology; 1996.

20. Hempelmann E and Egan TJ. Pigment Biocrystallization in Plasmodium falciparum. Trends in Parasitology 2002; 18 (1) : 11.

21. Robert A and Meunier B. Alkylating Properties Of Antimalarial Artemisinin Derivatives And Synthetic Trioxanes When Activated By Reduced Heme Model. Chem.Eur Journal, 2001; 4: 1287-1296

22. Ludwig et al. Artemisinins Target The SERCA of Plasmodium falciparum. Nature, 2003; 424.

23. Jones IW, Ley SV, Denholm AA, Lovell H, Wood A and Sinden RE. Sexual Development Of Malaria Parasites Vitro By Neem Extract And Its Semi-Synthetic Analogues. FEMS Microbiology 15, 1994.

24. Rochanakij S, Thebtaranonth Y, Yanjai $C$ and Yutharong J. Nimbolide, A Constituent Of Azadirachta indica Inhibits Plasmodium falciparum Culture. Southeast Asian Journal of Tropical Medicine and Public Health. 1995.

25. McKinnon S, Durst T, Arnaso JT, Angerhoferc, Pezzuto J, Sanchez - Vindas PE. Antimalarial Activity Of Tropical Meliaceae Extract And Gedunin Derivates. Journal Natural Product 1997; 60.

26. Omar S, Zhang J, MacKinnon S, Leaman D, Durst T, Philogene BJR, Arnason JT, Sanches-Vindas PE, Poveda L, Tames PA, Pezzuto J. Traditionally Used Antimalarials From The Meliaceae, Current Topics In Medicinal Chemistry, 2003; 3(2): 133- 139.

27. Sullvan Jr. Hemozoin: A Biocrystal Syntheszed during the degradation of Hemoglobin. In Biopolymers vol 9, Miscellaneous Biopolymers anda Biodegradation of Synthetic Polymers. Matsumura and A Steinbuchel Series Editor Wiley-UCH Verlag. Weiheim Germany: Gonbths \& Co; 2002; 129-163.

28. Peters W, Lin I, Robinson BL \& Walrust DC. The Chemotherapy Of Rodent Malaria, XL. The Action Of Artemisinin And Related Seswuiterpenes. Annals of Tropical Medicine and Parasitology; 1996; 80, 483-489.

29. Tripathi AK, Khan SI, Walker LA, Tekwani BL. Spectrophotometric Determination Of De Novo Hemozoin / $\beta$ hematin Formation An In Vitro Assay. J.Analytical Biochemistry, 2003; 325, 85 -91.

30. Abbas AK, Andrew HL, Pober JP. Cellular and Molecular Immunology. Fourth Edition. Philadelphia: W.B.Saunders Company; 2000.

31. Roth EF Jr, Brotman DS, Vanderberg JP, Schulman S. Malarial Pigment Error In The Estimation of Hemaglobin Content in Plasmodium falciparum Infected Red Cell: Implications For Metabolic And Biochemical Studies of the Erythtrocytic Phases of Malaria. Am.J.Trop.Med. Hyg. 1986; 35(5): 906-911.

32. Amodu OK, Adeyemo AA, Olumese PE, Ghadegesin RA. Intraleucocytic Malaria Pigment And Clinical Severity Of Malaria In Children. The Pediatric Infectious disease Jurnal. www.pidj.com/pj/re/pidj/fulltext. 00006454-200012000-00016.htm.

33. Metzger WG, Mordmuller BG, Kremsner PG. Malaria Pigment In Leucocytes. Trns,R.Soc,Trop,Med,Hyg; 1995; 89 : $637-638$ 